\title{
PTEROGLOSSUS ARACARI.
}

\author{
Cayenne Araçari.
}

\section{Specific Character.}

Pter. mundibulâ superiore stramineâ, maculâ latâ culminali nigrâ ; inferiore nigrâ ; rostro toto basi albocincto; femoribus olivaceis.

Head, neck and throat deep black; back, wings, upper tail-coverts and tail rich olive-green; primaries dark brown; rump blood-red; under surface greenish yellow, crossed on the upper part of the abdomen by a broad band of blood-red; thighs olive-brown; upper mandible straw-colour, with a broad mark of black along the culmen; under mandible black; at the base of both mandibles a raised band of straw-white; irides olive; orbits dark grey; bare skin beneath the feathers of the lower part of the sides of the reck and on the upper part of the flanks beneath the wing, deep red; legs and feet light green, their under surface tinged with olive.

Total length, 19 inches; bill, 5 ; wing, 6 ; tail, $7 \frac{1}{4} ;$ tarsi, $1 \frac{5}{5}$.

Ramphastos Arą̧ari, Linn. Syst. Nat., tom. i. p. 151.-Ib. Gmel. Edit., tom. i. p. 354.-Lath. Ind. Orn., vol. i. p. 138.

Tucana Brasiliensis viridis, Briss. Orn., tom. iv. p. 426. tab. 33. fig. 2.

Araçari, Marcgr. Bras., p. 217.--Ray, Orn., p. 44.-Will. Orn., p. 140. tab. 22.

Grigri, Buff. Hist. Nat. des Ois., tom. vii. p. 126.

Toucan verd du Brésil, Buff. PI. Enl., 166.

L'Araçari à ceinture rouge, Le Vaill. Ois. de Parad., tom. ii. p. 29. pl. 10.

Araçari Toucan, Lath. Gen. Syn., vol. i. p. 338.-Nat. Misc., pl. 198.-Shaw, Gen. Zool., vol. viii. p. 371. pl. 49.-Lath. Gen. Hist., vol. ii. p. 290.

Pteroglossus Araçari, Ill. Prod. Syst. Mamm. et Av., p. 202.-Temm. Man. d'Orn., 2nde Edit. tom. i. p. Ixxv.-Wagl. Syst. Av., Pteroglossus, sp. 2.-Gould, Mon. of Ramph., pl. 12.-Ib. Sturm's Edit, pl. -Gray and Mitch. Gen. of Birds, vol. ii. p. 403, Pteroglossus, sp. 1.-Bonap. Consp. Gen. Av., p. 93, Pteroglossus, sp. 1.

There can be little doubt that it was the present bird, and not its near ally the $P$. Wredi, which was known to Linnæus and the still earlier authors, for I find it was very correctly described by Marcgrave as long. back as 1649, his description being evidently taken from a Cayenne specimen, with the strongly marked culmen : his words are, "a thick black line upon the top of the bill running the whole length, with a tail six inches long and blackish green thighs." It is also the type of Illiger's genus Pteroglossus. The countries of Cayenne, Guiana, Surinam, and Northern Brazil constitute its native habitat, while Bahia, Rio de Janeiro, and Southern Brazil are inhabited by the $P$. Wiedi, from which bird it may be at once distinguished by its larger size, by its strongly toothed bill, by the greater breadth of the culminal black mark, and by its chestnut thighs.

The sexes offer little difference in colour, but the female may be readily recognized by the browner tint of her ear-coverts, and her somewhat smaller size.

The figures are of the natural size. 


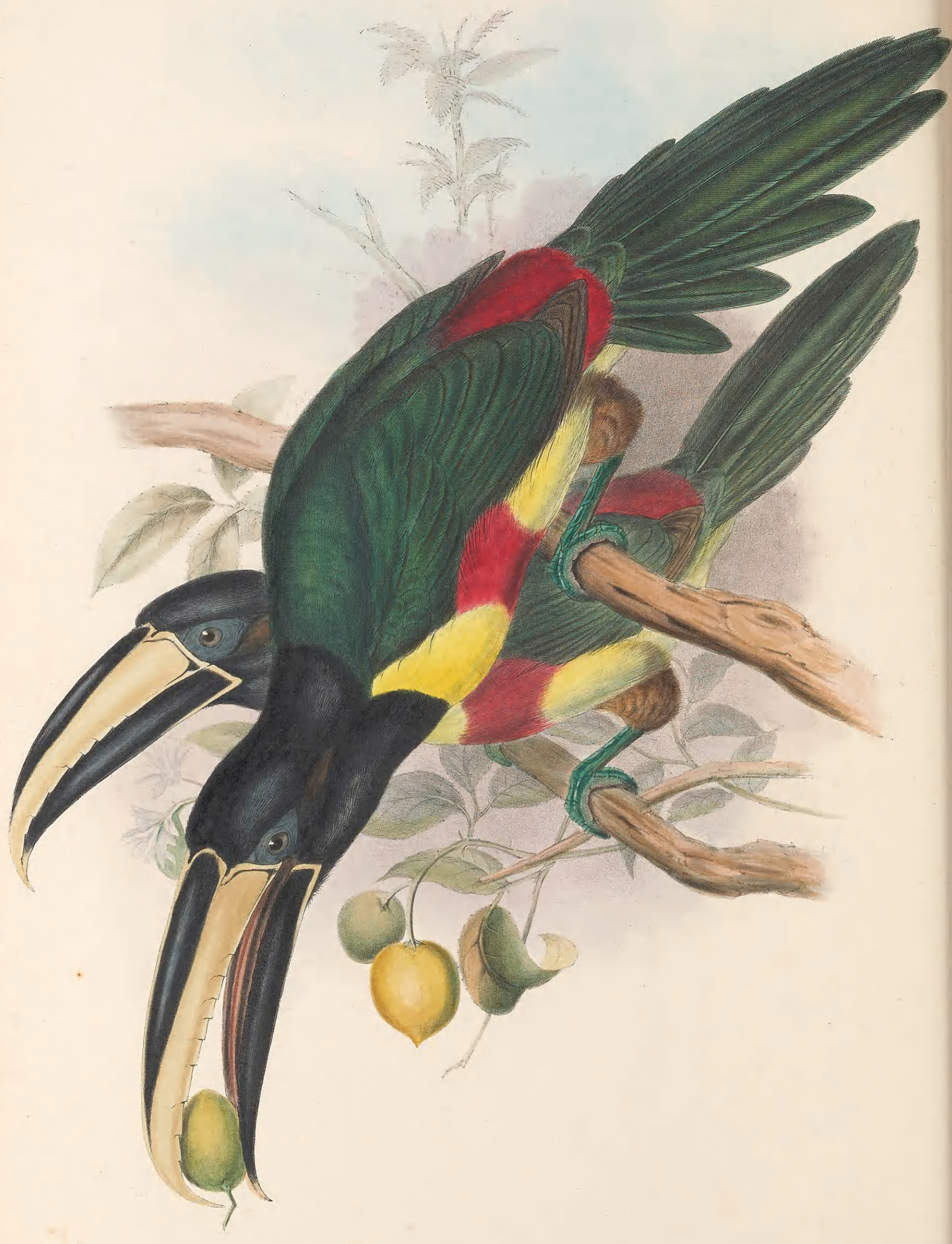

PTERDGIOSSTIS ARACARI. 


\section{$2 \mathrm{BHL}$ Biodiversity Heritage Library}

Gould, John. 1852. "Pteroglossus aracari., Cayenne Toucan [PI. 15]." A monograph of the Ramphastidae, or family of toucans -. https://doi.org/10.5962/p.322936.

View This Item Online: https://www.biodiversitylibrary.org/item/263319

DOI: https://doi.org/10.5962/p.322936

Permalink: https://www.biodiversitylibrary.org/partpdf/322936

\section{Holding Institution}

Smithsonian Libraries

\section{Sponsored by}

Biodiversity Heritage Library

\section{Copyright \& Reuse}

Copyright Status: Public domain. The BHL considers that this work is no longer under copyright protection.

This document was created from content at the Biodiversity Heritage Library, the world's largest open access digital library for biodiversity literature and archives. Visit BHL at https://www.biodiversitylibrary.org. 